\title{
Die Sicherheitsleistung für
}

die Prozesskosten 
(c) sellier european law publishers www.sellier.de 


\section{Die Sicherheitsleistung für die Prozesskosten}

Ein Vergleich des deutschen und englischen Zivilprozessrechts und ein Vorschlag für das Schiedsverfahrensrecht

Markus Altenkirch

\section{$\mathbf{s}|\mathbf{e}| \mathbf{l} \mid \mathbf{p}$}

sellier european law publishers 
ISBN (print) 978-3-86653-256-4

ISBN (eBook) 978-3-86653-988-4

Die Deutsche Nationalbibliothek verzeichnet diese Publikation in der Deutschen Nationalbibliografie; detaillierte bibliografische Daten sind im Internet über http://dnb.dnb.de abrufbar.

(C) 2013 by sellier european law publishers $\mathrm{GmbH}$, München.

Dieses Werk einschließlich aller seiner Teile ist urheberrechtlich geschützt. Jede Verwertung außerhalb der engen Grenzen des Urheberrechtsgesetzes ist ohne Zustimmung des Verlages unzulässig und strafbar. Das gilt insbesondere für Vervielfältigungen, Übersetzungen, Mikroverfilmungen und die Einspeicherung und Verarbeitung in elektronischen Systemen.

Herstellung: Karina Hack, München. Druck und Bindung: AZ Druck und Datentechnik GmbH, Kempten. Gedruckt auf säurefreiem, alterungsbeständigem Papier. Printed in Germany. 